\title{
Drug release from non-aqueous suspensions. II. The release of methylxanthines from paraffin suspensions
}

\author{
J.G. Fokkens and C.J. de Blaey \\ Department of Pharmaceutics, Pharmaceutical Laboratony. 35II GH Uirecht (The Netherlands) \\ (Received June 22nd, 1983) \\ (Accepted August 12th. 1983)
}

\begin{abstract}
Summary
The release of 3 methylxanthines, i.e. caffeine, theobromine and theophylline, from suspensions in liquid paraffin to an aqueous phase was determined in an in vitro apparatus. The release rates were determined as a function of the $\mathrm{pH}$ of the aqueous phase. It was proved that the release process was natural convection-regulated. The release rate per unit area was correlated to the solubility of the drug to the power 1.11. In case of the release of theophylline anhydrate from the suspensions a cake of theophylline hydrate was fortued at the interface paraffin/buffer, which resulted in a decreasing relcase rate. The formation of the cake was mostly completed within $20 \mathrm{~min}$, whereafter the release rate was exactly the same as the release rate of theophylline hydrate.
\end{abstract}

\section{Introduction}

The release of drugs from non-aqueous vehicles was reviewed in 1980 by Armstrong and James (1980a and b). From their survey of the literature it can be concluded that only seldom has a systematic approach been adopted to clarify the fundamental mechanisms involved in drug release from these dosage forms. An exception is the restarcl: concerning drug release from suppositories, where Bevernage and Polderman (1973) proposed a systematic approach which did result in several fundzmental studies (Crommelin and de Blaey, 1980a and b; Schoonen et al., 1979, 1980; Fokkens and de Blaey, 1982; Tukker and de Blaey, 1983a and b). In these studies a number of parameters like particle size and concentration of suspended drug were varied and the influence of these factors was measured.

Correspondence: J.G. Fokkens, Department of Pharmaceutics, Pharmaceutical Laboratory. Catharijnesingel 60, 3511 GH Utrecht, The Netherlands. 
In a previous study (Fokkens and de Blaey, 1982) we described the influence of the $\mathrm{pH}$ of the aqueous phase on the release of phenobarbital and phenobarbital sodium. From these experiments it was concluded that the release process was regulated at least in part by natural convection. This conclusion was based on differences between theoretically predicted ((E)SCRD-theory; Higuchi et al., 1958; Higuchi et al., 1964; Mooney et al., 1981a and 1981b) and our experimentally obtained data.

In order to determine to what extent in our set-up the release of drugs from non-aqueous suspensions was regulated by natural convection, further experiments were carried out using caffeine, theobromine and theophylline as suspended drugs. The release rates of these drugs from paraffin suspensions were determined and compared. Furthermore the influence of the $\mathrm{pH}$ of the aqueous phase on the release process was determined.

\section{Materials and Methods}

\section{Materials}

All drugs used were obtained from a commercial source; the quality conformed with the European Pharmacopoeia. Anhydrous caffeine and anhydrous theophylline were prepared by drying the monohydrates of these compounds at $110^{\circ} \mathrm{C}$ for at least $24 \mathrm{~h}$, whereafter the anhydrates were allowed to cool over silica gel in a desiccator. The change in the water content of the compounds during the drying process was followed by weighing. Caffeine, theobromine and theophylline were ball-milled and sieved (Alpine air-jet siever, Augsburg) and the sieve fractions of 32-50 $\mu \mathrm{m}$ were used in all experiments. Some physicochemical properties of the methylxanthines used are given in Table 1.

The liquid paraffin used (European Pharmacopoeia grade) had a viscosity of $71 \pm 1 \mathrm{mPa}$ at $20.0 \pm 0.1^{\circ} \mathrm{C}$, determined in a rotational viscometer. Before the suspensions were prepared, the paraffin was saturated with the particular methylxanthine used by shaking with an excess of this methylxanthine. All substances used for the preparation of the buffers were of reagent grade.

The buffers (with pH-values 5.0, 8.0 and 12.0) were prepared by adding either a $0.75 \mathrm{~mol} /$ litre phosphoric acid solution or a $0.1 \mathrm{~mol} /$ litre sodium hydroxide solution to a $0.1 \mathrm{~mole} /$ litre phosphate buffer with $\mathrm{pH}=7.0$.

\section{Methods}

The way in which the suspensions were prepared under humidity-controlled circumstances has been described earlier (Fokkens and de Blaey, 1982). The suspensions contained different amounts of drug, represented as percentages mass/mass. The experiments were carried out in a release apparatus as shown in Fig. 1 (rotational speed of $60 \mathrm{rpm}$, unless otherwise stated).

Approximately $10 \mathrm{~g}$ of the suspension was poured on top of the aqueous phase in the open glass tube and samples were taken autonatically from the aqueous phase at pre-set time intervals. The sample volume that was withdrawn was automatically 
TABLE 1

SOME PHYSICOCHEMICAL PROPERTIES OF METHYLXANTHINES

\begin{tabular}{lcclllll}
\hline Compound & $\mathrm{M}_{\mathrm{r}}{ }^{\prime}$ & $\begin{array}{l}\mathrm{C}_{\mathrm{s}}\left(21^{\circ} \mathrm{C}\right)^{2} \\
(\mathrm{~g} / \mathrm{l})\end{array}$ & $\mathrm{PK}_{\mathbf{c}^{\circ}}$ & $\begin{array}{l}\mathrm{D}^{3} \\
\left(\mathrm{~cm}^{2} \cdot \mathrm{s}^{-1}\right)\end{array}$ & $\mathrm{a}^{4}$ & $\begin{array}{l}\lambda \\
(\mathrm{Mm})\end{array}$ \\
\hline Caffeine & 194.2 & $21.7^{4}$ & $0.15>14$ & $5.35 \times 10^{-6}$ & 50.7 & 272 \\
Theobromine & 180.2 & $0.41^{\mathrm{b}}$ & 0.12 & 10.0 & $5.5 \times 10^{-6}$ & 56.5 & 273 \\
Theophylline & 180.2 & $11^{\mathrm{c}}$ & 3.5 & 8.6 & $5.5 \times 10^{-6}$ & 52.7 & 266.4 \\
Theophylline hydrate & 198.2 & $5.5^{\mathrm{d}}$ & 3.5 & 8.6 & $5.5 \times 10^{-6}$ & 47.9 & 266.4 \\
\hline
\end{tabular}

' Relative molecular mass.

2 Saturation concentration in 8 /litre.

${ }^{3}$ Dilfusion coefficient in $\mathrm{cm}^{2} / \mathrm{s}$. The diffusion coefficients are calculated, taking the D-value of phenobarbital as $5.35 \times 10^{-6} \mathrm{~cm}^{2} \cdot \mathrm{s}^{-1}$ (after Nogami et al.. 1969).

4 Absorptivity of the compounds in 8 /litre, measured at wavelength $\lambda(\mathrm{nm})$.

- Merck Index (1976).

'Determined at $19.9^{\circ} \mathrm{C}$. by taking samples in time from a suspension of theobromine in demineralized water. The suspension was mixed thoroughly $(>250 \mathrm{rpm})$ and samples were analyzed spectrophotometrically after suitable dilution.

'Fokkens (1983).

d Fokkens et al. (1983).

- Foye (1981).

replaced by fresh bulk fluid. The concentration of the methylxanthines in the aqueous phase was determined spectrophotometrically after suitable dilution of samples. All experiments were carried out at $21 \pm 0.5^{\circ} \mathrm{C}$.

Photographs were taken using an Olympus OM-2 camera, connected to an Olympus microscope. A few drops of suspension were placed on an object glass and a droplet of buffer was placed on top of the suspension. This droplet sank through the suspension and the behaviour of the drug particles in the paraffin/buffer interface was photographed.

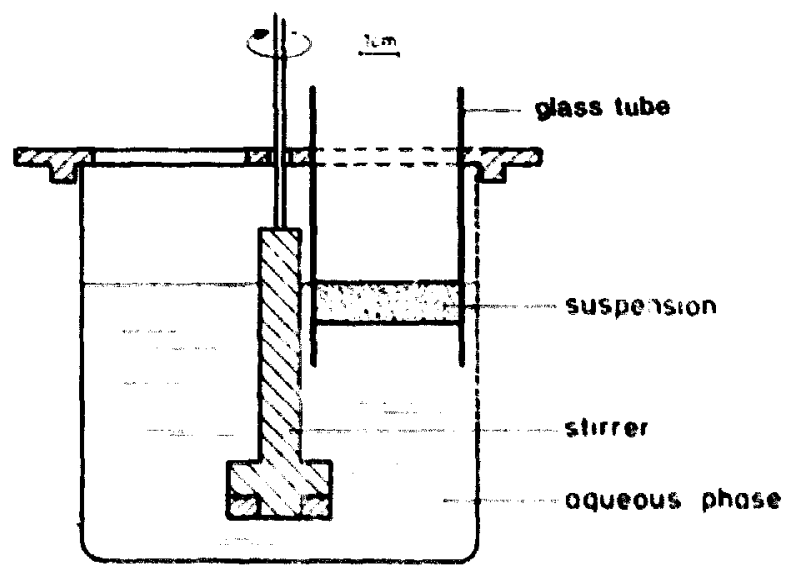

Fig. 1. Experimental set-up (see Folkens and De Blacy. 1982: reproduceo with permission of the copyrighl owner). 


\section{Results and Discussion}

Release studies were done in order to determine the influence that the $\mathrm{pH}$ of the bulk phase exerts on the release rates of caffeine, theobromine and theophylline from paraffin suspensions. A change in the $\mathrm{pH}$ of the aqueous phase, however, also implied a change in the solubility of two compounds, theobromine and theophylline. So, in order to allow comparison of the release rates of the 3 methylxanthines, the release process had to be dissolution rate-limited. This means that the dissolution rate of drug particles hanging at the paraffin/buffer interface is the rate-limiting step in the release process; so a further increase of the drug concentration in the suspension does not change the (initial) release rate. The results of the experiments with various concentrations of drug suspended in paraffin released to buffers with various $\mathrm{pH}$-values are described below for each drug separately.

\section{Caffeine}

The release rates of caffeine from paraffin suspensions to buffers with $\mathrm{pH}=\mathbf{8 . 0}$ are shown in Fig. 2.

Normally the shape of the release vs time curves is as shown in Fig. $2 A$, i.e. an initial steady release followed by a flattening of the curve when the suspension was exhausted of drug. Finally a plateau is reached when almost all the drug has been released; so this plateau concentration is a measure for the total amount released. However, when the concentration of caffeine was increased above $3 \%$ the formation of a 'fluffy sediment' in the paraffin layer was observed, and the release process stopped long before all the drug had come out of the suspension. This was always observed with the $8 \%$ suspensions and twice with the $5 \%$ suspensions (see Fig. $2 \mathrm{C}$ and $2 \mathrm{~B}$, respectively). The (macroscopically observed) formation of the sediment could be prevented by adding $0.02 \%$ dioctyl sodium sulphosuccinate (DOSS-Na) to the suspension. This, however, did not only prevent the formation of a sediment, which was macroscopically observed, but it also caused an increase in the initial steady state release rate of caffeine. Particles fell through the interface, which points to a change in interfacial tension and/or wettability. The curves shown in Fig. 3 illustrate this effect; all initial release rates are given in Table 2.

From the results shown in this table it can be concluded that the release rate of caffeine from paraffin suspensions is $0.38 \mathrm{mg} /\left(\mathrm{cm}^{2} \cdot \min \right)$ in the dissolution ratelimited processes and that $3 \%$ seems to be a more or less critical concentration with regard to this dissolution rate-limiting effect. The latter conclusion was drawn since the release rate to buffer with $\mathrm{pH}=12.0$ was about $20 \%$ lower than with bulk $\mathrm{pH}$-values of 5.0 and 8.0. No degradation of caffeine in the aqueous phase at $\mathrm{pH}=12.0$ was found in stability studies. In these studies the absorbance of a $0.001 \%$ solution of caffeine was followed in time and found to be constant over more than 4 h.

\section{Theobromine}

The release of theobromine suspended in liquid paraffin to buffers with various pH-values resulted in the following data (Table 3 ). 

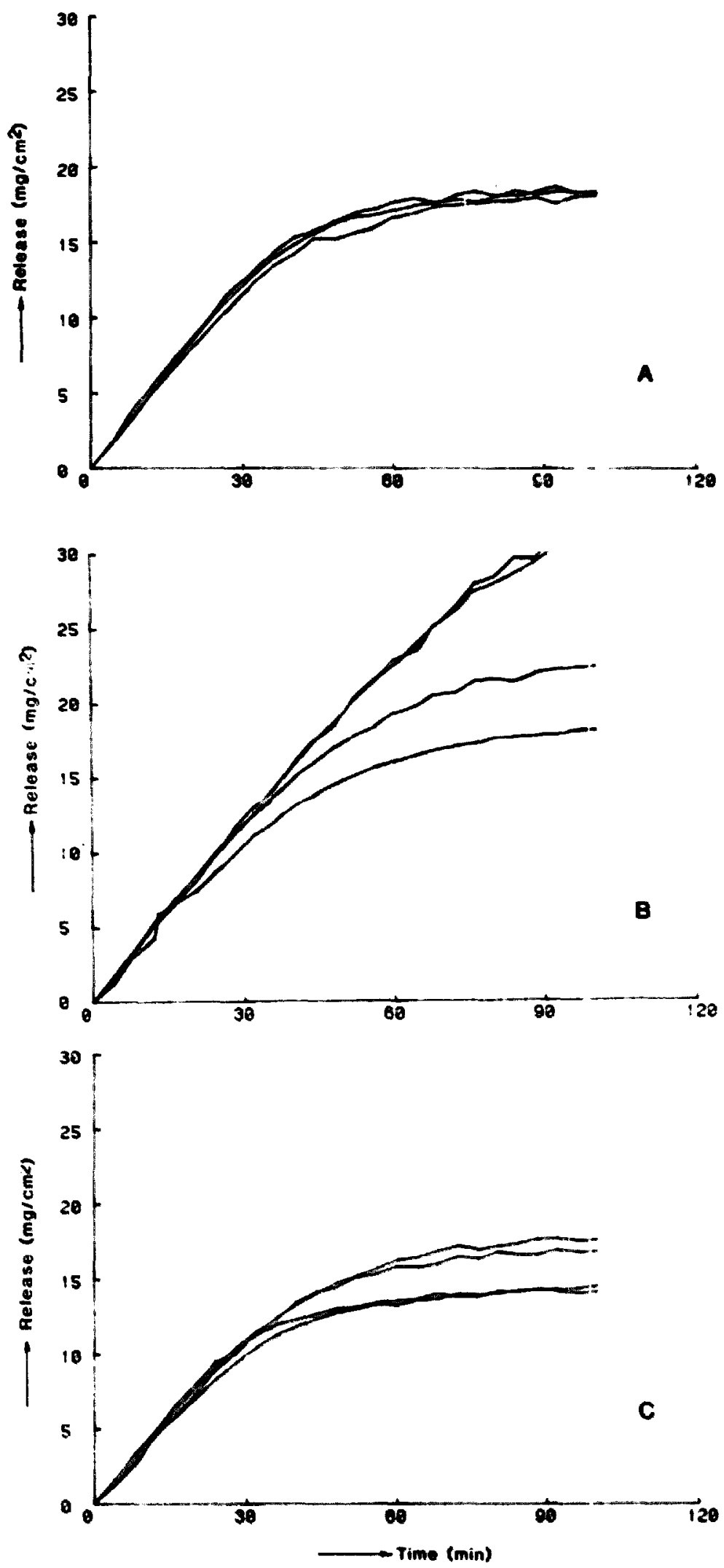

Fis. 2. Release of caffeine $\left(\mathrm{mg} \cdot \mathrm{cm}^{-2}\right)$ from suspensions to a buffer with $\mathrm{pH}=8.0$. All curves represent separate experiments, A: 3\% caffeine suspension. B: $5 \%$ caffeine suspension. C: 8\% caffcine suspension. 
TABLE 2

RELEASE RATES $\left(\mathrm{mg} \cdot \mathrm{cm}^{-2} \cdot \mathrm{min}^{-1}\right.$ ) OF CAFFEINE FROM PARAFFIN SUSPENSIONS TO BUFFERS WITH VARIOUS PH-VALUES

\begin{tabular}{lllll}
\hline $\mathrm{pH}$ & \multicolumn{4}{l}{ Concentration of caffeine in the suspension } \\
\cline { 2 - 5 } & $3 \%$ & $5 \%$ & $8 \%$ & $8 \%+0.02 \%$ DOSS-Na \\
\hline 5.0 & $0.383 \pm 0.003$ & - & - & - \\
8.0 & 0.392 & $0.37 \pm 0.03$ & $0.38 \pm 0.02$ & 0.857 \\
& 0.372 & & & 0.843 \\
12.0 & $0.315 \pm 0.005$ & - & - & - \\
\hline
\end{tabular}

A standard deviation is given when 4 experiments were carried out. Where two expertments were carried out, the individual values are given. $-=$ not determined.

From the results presented in this table it can be concluded that for almost all concentrations the release process was dissolution rate-limited. A practical problem occurred rather frequently, i.e. theobromine particles fell through the paraffin/buffer interface immediately after the suspensions had been poured into the glass tubes. As expected (with regard to the $\mathrm{pK}_{\mathrm{a}}$-value of theobromine) no influence of the $\mathrm{pH}$ of the buffer was observed when the $\mathrm{pH}$ was well below 10 . When the $\mathrm{pH}$ of the aqueous phase was increased to 12.0 , an up to 30 -fold increase in the theobromine release rate was found.

\section{Theophylline}

The $\neg \mathrm{K}_{\mathrm{a}}$-value of theophylline is 8.7 and hence it was expected that the release rate of this methylxanthine would increase when the $\mathrm{pH}$ of the aqueous phase

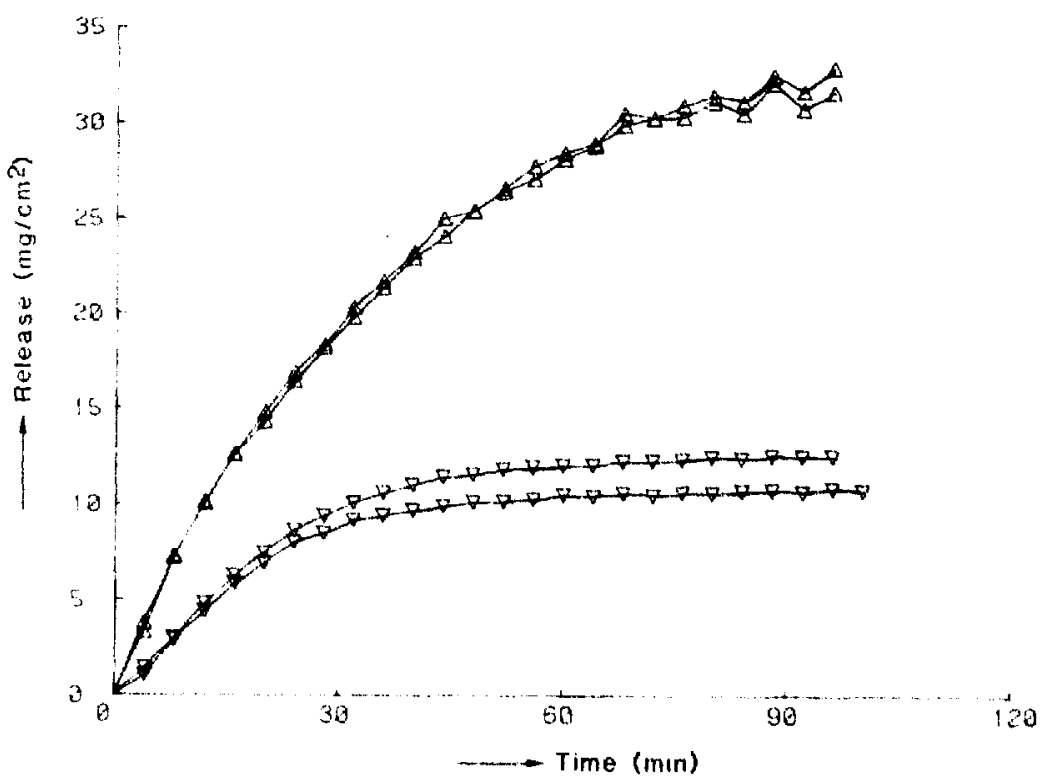

Fig. 3. Release of caffeine $\left(\mathrm{mg} \cdot \mathrm{cm}^{-2}\right.$ ) from an 8 suspension in paraffin to buffer with $\mathrm{pH}=8.0$. All curves represent separate experiments. $\nabla$, without DOSS-Na; $\Delta$, with $0.02 \%$ DOSS-Na in the suspension. 
increased from 5.0 to 8.0 or 12.0. In analogy with the experiments carried out with theobromine the release rates of theophylline were determined. In dissolution rate-limited release processes, however, the formation of a cake at the aqueous side of the paraffin/buffer interface was observed and simultaneously a decrease in release rate occurred. The cake covered the total interface; sometimes it broke loose from the interface and fell to the bottom of the beaker. When the cake was hit by the stirrer during its fall, it remained intact. This points to a rather firm structure.

Microscopical observations showed that the cake consisted of a crystalline network of needles of theophylline hydrate (Fokkens et al., 1983). A series of photographs illustrating the caking process is reproduced in Fig. 4.

A series of experiments with different concentrations of theophylline in suspension were carried out. The results obtained are represented in Table 4.

The release rates of theophylline are represented as the release rates of theophylline hydrate, i.e. the slopes were calculated from point a in Fig. 5 onwards.

As can be seen from the theophylline release curve shown in Fig. 5, the caking process was completed within approximately $20 \mathrm{~min}$, whereafter the release rate was exactly the same as the release rate of theophylline hydrate. The results presented in Table 4 show that the release rate of theophylline increased with increasing bulk pH.

On the basis of the Noyes-Whitney equation the diffusion boundary layers $\left(\delta_{N}\right)$ were calculated for the 3 methylxanthines. The $\delta_{\mathrm{N}}$-values (bulk pH $=5.0$ ) found for caffeine, theobromine and theophylline were 182,330 and $252 \mu \mathrm{m}$, respectively. This suggested a non-forced convection-regulated release process, since in a forced convection-driven process these $\delta_{\mathrm{N}}$-values should have been the same. This finding is in agreement with the results obtained in the same set-up as used here, with phenobarbital as the suspended drug (Fokkens and de Blaey, 1982). Further investigations were carried out in order to find out to what extent the release process was regulated by natural convection and to what extent by forced convection. Therefore the influence that variation in experimental conditions had on the release process was investigated; rotational speed and distance from the bottom of the glass tube to the suspensicin/buffer interface were varied.

\section{TABLE 3}

RELEASE RATE (mg $\cdot \mathrm{cm}^{-2} \cdot \mathrm{min}^{-1}$ ) OF SUSPENDED THEOBROMINE TO BUFFERS WITH VARIOUS PH-VALUES

\begin{tabular}{|c|c|c|c|c|c|}
\hline \multirow[t]{2}{*}{$\overline{\mathrm{pH}}$} & \multicolumn{5}{|c|}{ Concentration } \\
\hline & $\overline{0.5 \%}$ & $1 \%$ & 38 & 58 & 88 \\
\hline \multirow[t]{2}{*}{5.0} & $\overline{0.004}$ & $-\cdots$ & 0.004 & 0.003 & 0.004 \\
\hline & 0.004 & $-\cdots$ & 0.004 & 0.003 & 0.004 \\
\hline \multirow[t]{2}{*}{8.0} & 0.004 & - & 0.004 & 0.004 & 0.004 \\
\hline & 0.004 & $-\cdots$ & $\ldots$ & 0.004 & 0.004 \\
\hline \multirow[t]{2}{*}{12.0} & 0.096 & 0.146 & 0.134 & 0.118 & 0.136 \\
\hline & 0.104 & 0.132 & $\begin{array}{l} \pm 0.008 \\
(n=4)\end{array}$ & 0.121 & 0.146 \\
\hline
\end{tabular}

- Particles fell through the interface. 
An increase in the rotational speed from 40 to $60 \mathrm{rpm}$ did not influence the release rate. A further increase to $80 \mathrm{rpm}$ caused an increase of approximately $25 \%$ in the release rate. So it was concluded from these results that the release process was regulated by natural convection at a rotational speed of $60 \mathrm{rpm}$. This was confirmed by the results obtained with experiments with varying distances between the inter-

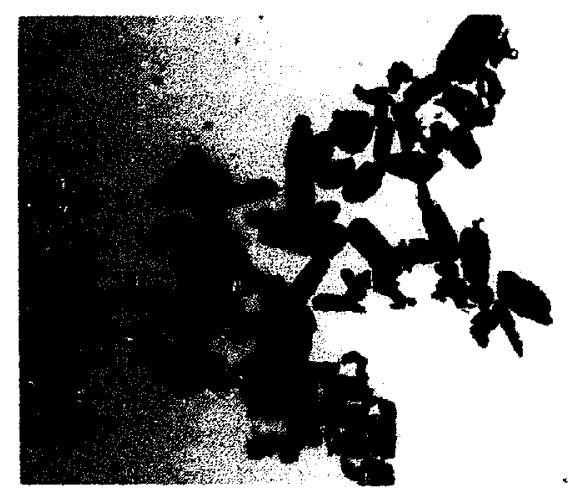

a

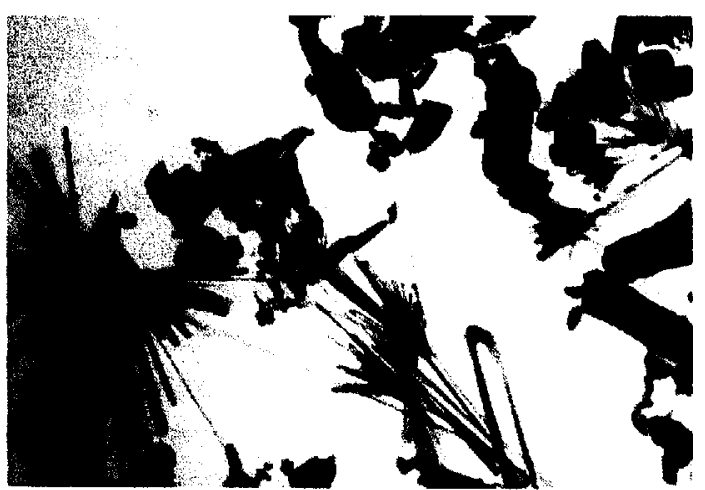

b

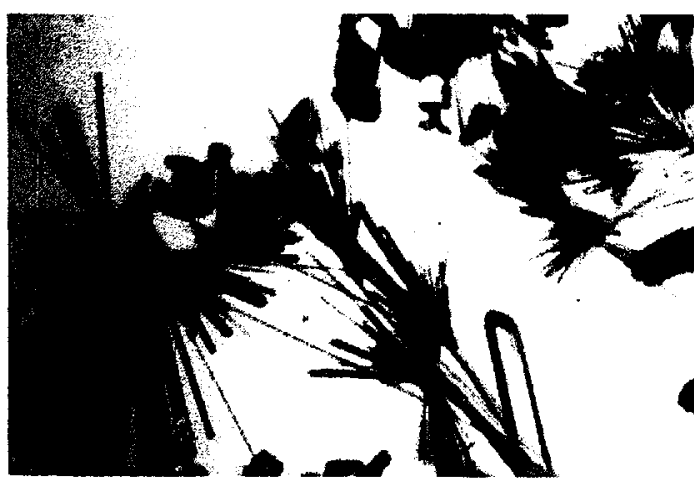

c

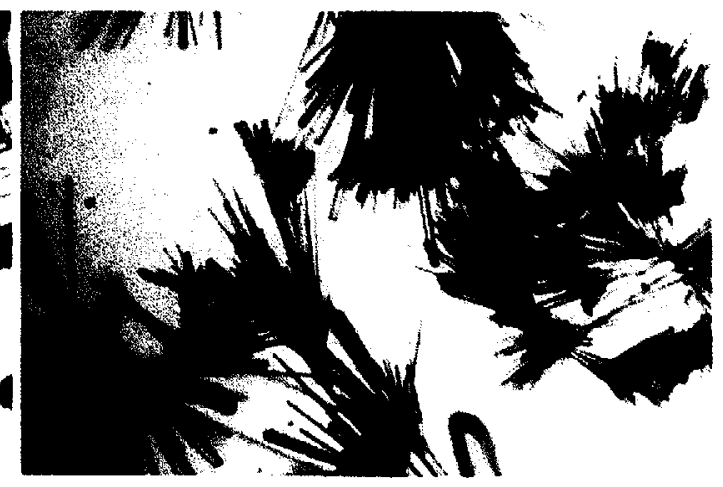

d

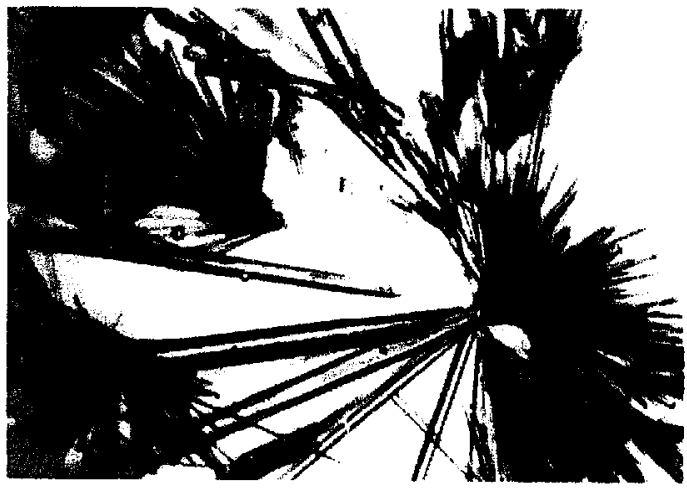

$\mathrm{e}$

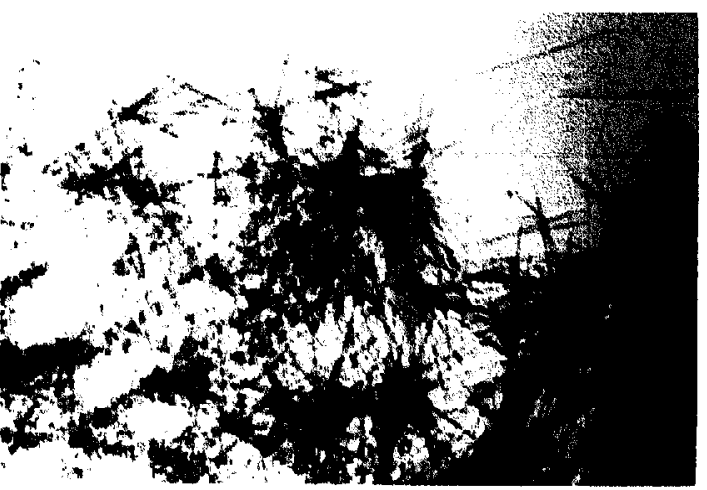

f

1tg. 4. The crystailisation process of theophylline hydrate. a: initial situation: theophylline anhydrate particles in the incerface paraffin buffer $\mathrm{pH}=5.0 \mathrm{~h}$ e: the growing process of needles of theoplivlline hydrate. fi fiual suluation-cake. 
TABLE 4

RELEASE RATE $\left(\mathrm{mg} \cdot\left(\cdot \mathrm{n}^{-2} \cdot \mathrm{min}^{-1}\right)\right.$ OF THEOPHYLLINE FROM PARAFFIN SUSPENSIONS TO BUFFERS WITH VARIOUS PH-VALUES $(n=4)$

\begin{tabular}{rlllll}
\hline pH & \multicolumn{2}{c}{ Concentration } & & & \\
\cline { 2 - 6 } & $0.5 \%$ & $1 \%$ & $3 \%$ & $5 \%$ & $8 \%$ \\
\hline 5.0 & - & - & $0.077 \pm 0.003 *$ & $0.077 \pm 0.003 * *$ & - \\
8.0 & $0.109 \pm 0.010$ & $0.150 \pm 0.012$ & $0.115 \pm 0.010$ & $0.107 \pm 0.010$ & - \\
12.0 & $0.207 \pm 0.033$ & $0.452 \pm 0.023$ & $0.451 \pm 0.055$ & & $0.436 \pm 0.098$ \\
\hline
\end{tabular}

The release rates are calculated from the steady-state parts of the release vs time curves and represent the rates of theophylline hydrate. $-=$ not determined. * ** Determined for a 29 and a 4 t theophylline suspension, respectively.

face and the bottom of the glass tube. Variation of this distance between 1 and 15 $\mathrm{mm}$ did not cause any difference in the release rate of theophylline, illustrating that no measurable changes in the release rate of theophylline occurred after the (hydrodynamical) situation in the glass tube was changed.

From these observations it was concluded that in the release apparatus used and under the circumstances mentioned the release process is regulated by natural convection only. This implied that the release rate should in some way be dependent on density differences between saturated solctions occurring at the interface (and so on saturation concentrations) and bulk fluid. In order to test whether such a correlation exists, all experimental data available so far (of non-ionized species) were collected (Table 5) and plotted as shown in Fig. 6.

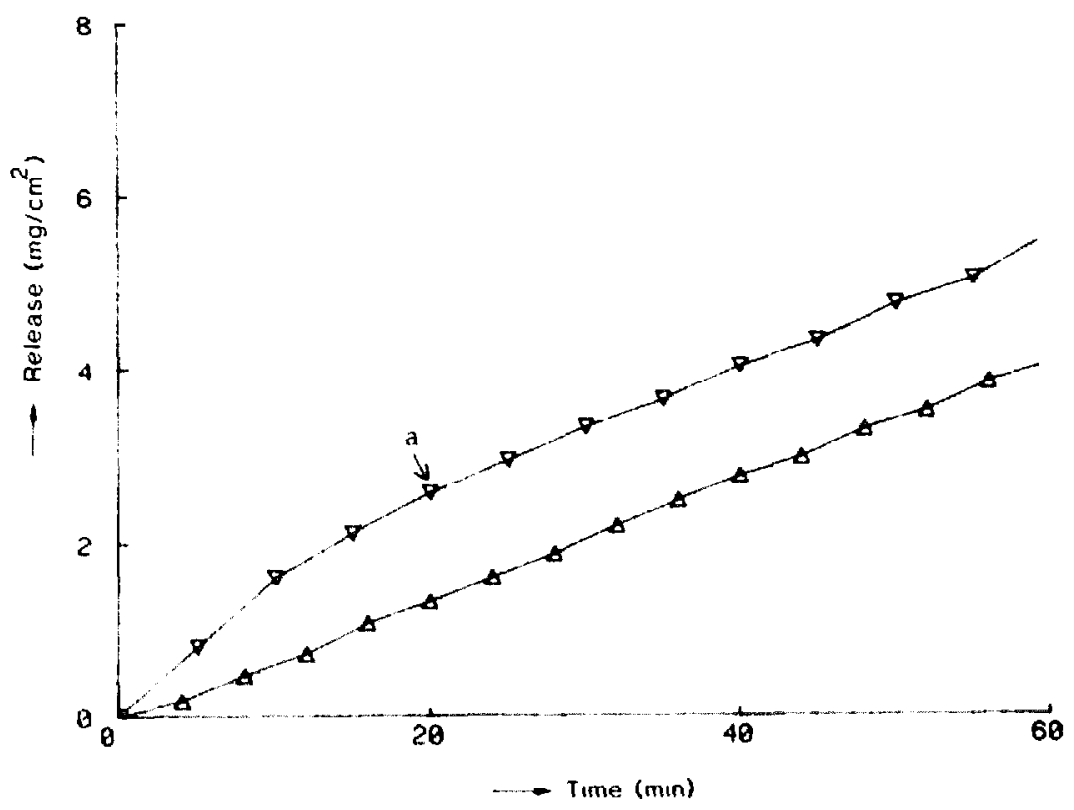

Fig. S. Release of theophylline from paraffin suspensions to huffer with $\mathrm{pH}=\mathbf{5 . 0}$. $\Delta$, theophylline hydrate; $\Gamma$. theophylline. Point a indicates that the caking process of theophylline hydrate is completed. 


\section{TABLE 5}

SUMMARY OF SATURATION CONCENTRATION IN WATER, $C_{s}$, AND EXPERIMENTAL RELEASE RATES FROM SUSPENSIONS OF SEVERAL COMPOUNDS

\begin{tabular}{lcl}
\hline Compound & $\begin{array}{l}\mathrm{C}_{\mathrm{s}}\left(21^{\circ} \mathrm{C}\right) \\
(\mathrm{g} / \mathrm{l})\end{array}$ & $\begin{array}{l}\text { Observed release rate } \\
\left(\mathrm{mg} \cdot \mathrm{cm}^{-2} \cdot \mathrm{min}^{-1}\right)\end{array}$ \\
\hline Caffeine & $21.7^{\mathrm{a}}$ & 0.380 \\
Paracetamol & $14.2^{\mathrm{b}}$ & $0.18^{\mathrm{c}}$ \\
Theophylline hydrate & $5.5^{\mathrm{a}}$ & 0.077 \\
Chloramphenicol & $2.5^{\mathrm{b}}$ & $0.03^{\mathrm{c}}$ \\
Theobromine & $0.4^{\mathrm{a}}$ & 0.004 \\
\hline
\end{tabular}

a See Table 1.

b Martindale (1977).

${ }^{c}$ Crommelin and de Blaey (1980b).

Plotting the data as shown in Fig. 6, we obtained a straight line, which can be described by the following empirical equation

$\log \mathrm{R}^{\prime}=\mathrm{a}+\mathrm{b} \log \mathrm{C}^{\prime}$

where $a=1.76 \pm 0.04, b=1.11 \pm 0.03$ and $\log R^{\prime}$ and $\log C^{\prime}$ represent the logarithms of the data given in Table 5 .

Therefore in a natural convection-regulated release process the release rate is linearly related to the saturation concentration to the power 1.11. This power differs from that found by Thomas and Armistead (1968) who calculated from their experiments (release of $\mathrm{KCl}$ to various dissolution media) that the release rate was

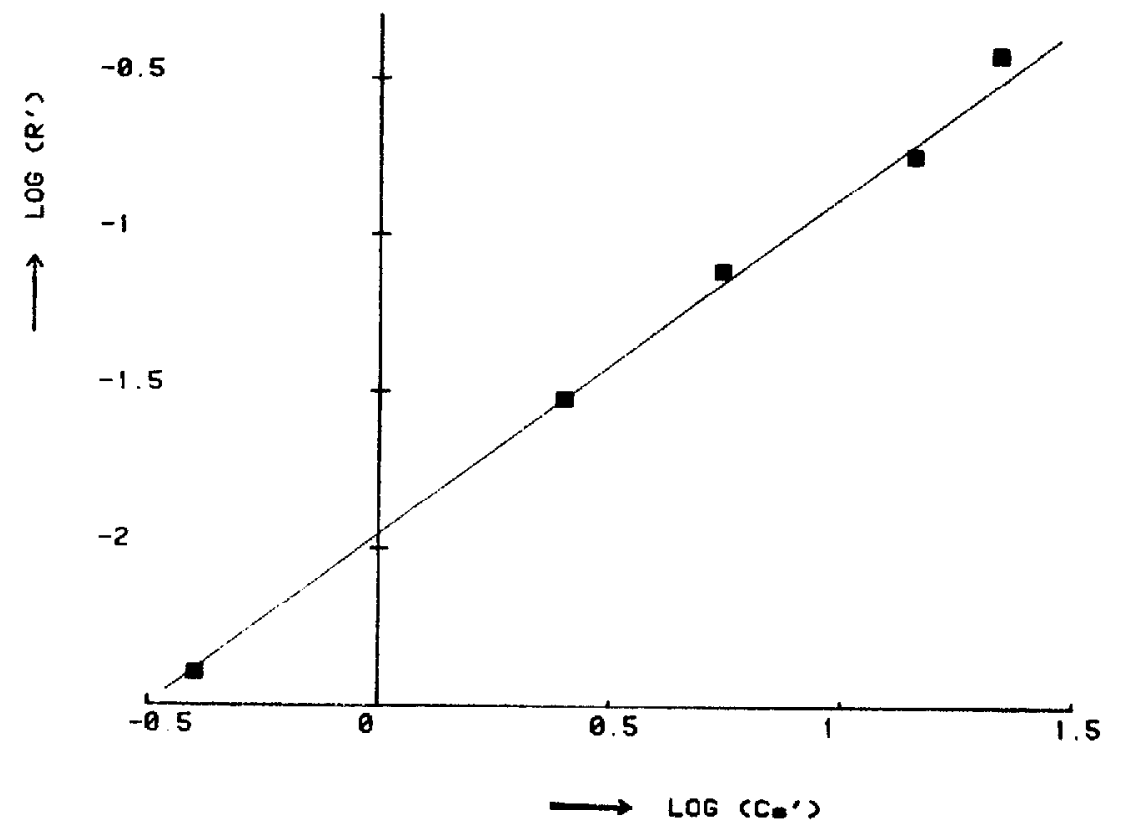

Fig. 6. Plot of $\log \left(R^{\prime}\right)$ versus $\log \left(C s^{\prime}\right)$. For further explanation see text. 
equal to the saturation concentration to the power 1.33. This difference between the two values mentioned can not easily be explained. We believe that the release of drugs under natural convection-driven circumstances to an aqueous phase is described by Eqn. 1 .

\section{Acknowledgement}

The authors wish to thank Mr. J.G.M. van Amelsfoort and Mr. L. van Bloois for carrying out part of the experiments.

\section{References}

Armstrong. N.A. and James, K.C., Drug release from lipid-based dosage forms. I. Int. J. Pharm., 6 (1980a) 185-193.

Armstrong, N.A. and James, K.C., Drug release from lipid-based dosage forms. II. Int. J. Pharm., 6 (1980b) 195-204.

Bevernage, K.B.M. and Polderman, J., Farmaceutische lessen (zetpillen). Pharm. Weekbl., 20 (1973) 429-433.

Crommelin, D.J.A. and de Blaey, C.J., In vitro release studies on drugs suspended in non-polar media. I. Release of sodium chloride from suspensions in liquid parafin. Int. J. Pharm., 5 (1980a) 305-316.

Crommelin, D.J.A. and de Blaey, C.J., In vitro release studies on drugs suspended in non-polar media. 11. The release of paracetamol and chloramphenicol from suspensions in liquid paraffin. Int. J. Pharm., 6 (1980b) 29-42.

Fokkens, J.G., In Vitro Drug Release from Non-Aqueous Suspensions, Ph.D. Thesis, Utrecht, February 1983.

Fokkens, J.G., van Amelsfoort, J.G.M., de Blaey, C.J., de Kruif, C.G. and Wilting, J., A thermodynamic study of the solubility of theophylline and its hydrate. Int. J. Pharm., 14 (1983) 79-92.

Fokkens, J.G. and de Blaey. C.J., Drug release from non-aqueous suspensions I. Release of phenobarbital and phenoba bital sodium from paraffin suspensions., Pharm. Weekbl. Sci. Edn., 4 (1982) 117-121.

Foye, W.O., Principles of medicinal Chemistry, 2nd Edn., Lea and Febiger, 1981, Philadelphia.

Higuchi, W.I., Partott, E.L., Wurster, D.E. and Higuchi, T., Investigation of drug release from solids. II. Theore ical and experimental study of influences of bases and buffer on rates of dissolution of acidic solids. I. Am. Pharm. Ass. Sci. Edn., 47 (1958) 376-383.

Higuchi, V.I., Nelson, E. and Wagner, J.G., Solubility and dissolution rates in reactive media., J. Pharm. Sci., 53 (1964) 333-335.

Martindale, The Extra Pharmacopoeia, 26 Edn., London, The Pharmaceutical Press, 1975.

Merck Index, 9th Edn., Merck and Co., Rahway, NJ, U.S.A., 1976.

Mooney, K.G., Mintun, M.A., Himmelstein, K.J. and Stella, V.J., Dissolution kinetics of carboxylic acids. I. Effect of pH under unbuffered conditions., J. Pharm. Sci., 70 (1981a) 13-22.

Mooney, K.G., Mintun, M.A., Himmelstein, K.J. and Stella, V.J., Dissolution kinetics of carboxylic acids. II. Effect of buffers. J. Pharm. Sci., 70 (1981b) 22-32.

Nogami, H., Nagai, T. and Yotsuyanagi, T. Dissolution phenomena of organic medicinals involving simultaneous phase changes. Chem. Pharm. Bull., 17 (1969) 499-509.

Schoonen, A.J.M., Moolenaar, F. and Huizinga, T., Release of drugs from fatty suppository bases. I. The release mechanism. Int. J. Pharm., 4 (1979) 141-152.

Schoonen, A.J.M., Moolenaar, F., Reuvers, F. and Huizinga, T., Release of drugs from fatiy suppository bases. II. A rate-limiting interfacial process. Int. J. Pharm., 7 (1980) 29-43.

Thomas. D.G. and Armistead, R.A.. Concentration-gradient-driven convection: experiments. Science, 160 (1968) 995-996. 
Tukker, J.J. and de Blaey, C.J., The addition of colloidal silicum oxide to suspension suppositories I. The impact on in vitro release and bioavailability. Acta Pharm. Technol, 29 (1983a) in press.

Tukker, J.J. and de Blaey, C.J., The addition of colloidal silicum oxide to suspension suppositories II. The impact on rheological behaviour in vitro and in vivo. Acta Pharm. Technol., (1983b) submitted for publication. 